\title{
EVALUASI AKHIR GALUR HARAPAN KACANG PANJANG (Vigna sesquipedalis L. Fruwirth) POLONG UNGU
}

\section{A FINAL EVALUATION OF EXPECTED LINES OF YARDLONG BEAN (Vigna sesquipedalis L. Fruwirth) WITH PURPLE PODS}

\author{
Ratna Zulfarosda*, Damanhuri, Budi Waluyo dan Kuswanto \\ Fakultas Pertanian, Universitas Brawijaya, Jln. Veteran, Malang 65145, Indonesia \\ *Email: ratnazulfarosda@gmail.com
}

\begin{abstract}
A Final Evaluation of Expected Lines of Yardlong Bean (Vigna sesquipedalis L. Fruwirth) with Purple Pods. Evaluation toward expected lines yardlong bean purple pod ability conducted to obtain lines which have superiority in yield, yiled components and other traits. Evaluation was done by analyzed adaptation and stability test. Research towards 6 lines was conducted at 6 different locations based on altitude (the middle land and low land), condition areas (rainfall and temperature) as well as the conditions of cultivation (with and without mulch application). Adaptation and stability test provides information related to lines response of environmental condition for recommended cultivation on specific or all types environment. The results showed superiority pod weight per hectare of BU 1 (9,18 tha $\left.a^{-1}\right)$ followed

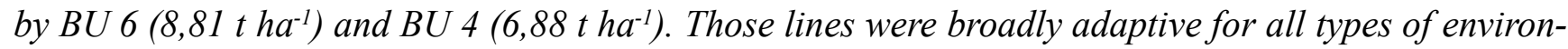
ments. Lines that adaptive in spesific environment, $B U 2\left(8,03 \mathrm{t} \mathrm{ha}^{-1}\right)$ produced optimal yield on marginal environment, while BU 5 (10,03 tha $\left.\mathrm{s}^{-1}\right)$ adaptive at productive environment. Based on lines description, all lines have superiority of purple pod colored and specifically BU 3 had highest anthocyanins content.
\end{abstract}

Keywords: Adaptation, stability, yield, yardlong bean, purple pod

\begin{abstract}
ABSTRAK
Evaluasi Akhir Galur Harapan Kacang Panjang (Vigna sesquipedalis L. Fruwirth) Polong Ungu. Evaluasi terhadap galur harapan kacang panjang polong ungu dilakukan untuk memperoleh galur yang memiliki keunggulan hasil panen, komponen hasil serta sifat-sifat yang lain. Evaluasi dilakukan melalui analisis uji adaptasi dan stabilitas. Pengujian terhadap 6 galur harapan dilakukan pada 6 lingkungan yang berbeda berdasarkan ketinggian tempat (dataran tengah dan dataran rendah), kondisi iklim (temperatur udara, kelembaban dan curah hujan) serta teknik budidaya (dengan dan tanpa mulsa). Uji adaptasi dan stabilitas memberikan informasi terkait respon galur terhadap kondisi lingkungan penanaman sehingga varietas yang dilepas dapat direkomendasikan pada spesifik lingkungan atau pada semua tipe lingkungan. Hasil penelitian ini menunjukkan galur BU 1 memiliki keunggulan bobot polong per hektar dengan rerata hasil yang tinggi $\left(9,18 \mathrm{tha}^{-1}\right)$ diikuti oleh galur BU $6(8,81 \mathrm{t}$ $\left.\mathrm{ha}^{-1}\right)$ dan BU $4\left(6,88 \mathrm{tha}^{-1}\right)$ dengan kemampuan beradaptasi umum untuk semua tipe lingkungan. Galur BU 2 menunjukkan keunggulan dalam menghasilkan bobot polong per hektar optimal pada lahan marjinal $\left(8,03\right.$ tha $\left.^{-1}\right)$,
\end{abstract}


sedangkan galur BU 5 beradaptasi pada lahan produktif $\left(10,03 \mathrm{tha}^{-1}\right)$. Berdasarkan deskripsi galur, seluruh galur memiliki keunggulan warna polong ungu dan secara khusus galur BU 3 memiliki keunggulan kadar antosianin paling tinggi diantara galur yang diuji.

Kata Kunci : Adaptasi, stabilitas, hasil, kacang panjang, polong ungu

\section{PENDAHULUAN}

Penelitian kacang panjang polong ungu telah dilakukan sejak tahun 2010. Hasil penelitian terakhir menunjukkan kacang panjang polong ungu memiliki potensi hasil per hektar mencapai 6.87 tha $^{-1}$ (Paramitha, 2014). Kacang panjang polong ungu diperoleh dari hasil persilangan kacang panjang koleksi Universitas Brawijaya Varietas Putih Super dengan MLG 15151. Hasil persilangan diperoleh genotip kacang panjang dengan produktifitas tinggi serta tahan hama aphid dan muncul genotip kacang panjang dengan karakter unik yakni polong berwarna ungu. Polong ungu mengindikasikan aktivitas antioksidan karena adanya kandungan anthosianin yang sering kali menjadi objek penelitian karena berperan penting dalam menangkap radikal bebas dalam tubuh (Suda et al., 2003), sebagai upaya pencegahan penyakit kronis (Laga et al., 2014), serta anti-kanker dan anti-virus (Zhao et al., 2009). Hasil penelitian menunjukkan kacang panjang polong ungu lebih toleran terhadap serangan hama dan penyakit serta tahan terhadap cekaman air (Kuswanto et al., 2013). Uji keunggulan kacang polong ungu tersebut penting dilakukan untuk mengetahui karakter unggul yang dimiliki genotip tersebut.

Karakter kualitatif seperti warna polong dikendalikan oleh satu gen (single gene), tetapi tidak tertutup kemungkinan bahwa karakter tersebut dikendalikan oleh banyak gen (polygene). Interaksi antar-gen dapat terjadi dan menghasilkan fenotip yang beragam. Interaksi gen pada lokus berbeda dan mengatur karakter yang sama disebut dengan interaksi non-alel atau epistasis. Epistasis menyebabkan penyimpangan rasio fenotip hukum mendel karena ekspresi suatu gen tertutupi oleh ekspresi gen lain (Brown dan Caligari, 2008).

Tanaman yang ditanam pada suatu lingkungan akan mengalami interaksi genotip dengan lingkungan. Dikatakan terjadi interaksi genotip x lingkungan apabila penampilan beberapa genotip berubah akibat perbedaan kondisi lingkungan (Asfaw et al., 2008; Escobar et al., 2011; Choukan, 2011). Interaksi dapat diketahui melalui analisis ragam hasil percobaan dari beberapa genotip yang ditanam pada beberapa kondisi lingkungan maupun musim tanam. Karakter genotip tertentu dapat menunjukkan perbedaan apabila ditanam pada kondisi lingkungan yang berbeda. Menurut Baihaki (1990), varietas unggul yang berdaya hasil tinggi dapat memanfaatkan kemampuan wilayah setempat secara optimal. Kelebihan varietas unggul dapat dilihat dari daya adaptasi yang luas terhadap berbagai keadaan lingkungan tumbuh, atau juga dapat beradaptasi sempit pada lingkungan spesifik (Kasim dan Djunainah, 1993). Jika ditemukan pengaruh nyata dari interaksi genotip x lingkungan, maka dapat 
diketahui stabilitas hasil melalui uji stabilitas (Singh dan Chaudhary, 1979). Metode yang digunakan untuk menduga adaptabilitas dan stabilitas hasil ialah dengan melakukan pengujian pada beberapa lingkungan tumbuh yang berbeda (Singh dan Chaudhary, 1979). Ada beberapa metode yang digunakan untuk menduga daya adaptasi dan stabilitas hasil salah satunya ialah metode Finlay-Wilkinson (1963) dan Eberhart-Russel (1966).

Berdasarkan hasil seleksi dan uji daya hasil kacang panjang polong ungu, diperoleh enam galur harapan kacang panjang polong ungu diantaranya BU 1, BU 2, BU 3, BU 4, BU 5, dan BU 6 (Paramitha, 2014). Peraturan Menteri Pertanian No.38 (2011) tentang Pendaftaran Varietas Tanaman Hortikultura Pasal 10 menyebutkan bahwa setiap varietas yang didaftarkan harus memiliki hasil uji keunggulan. Dalam penelitian ini, uji keunggulan dilakukan melalui uji adaptasi dan stabilitas pada 6 lingkungan yang berbeda. Perbedaan lingkungan dalam penelitian ini berdasarkan ketinggian tempat (dataran tengah dan dataran rendah), kondisi iklim (temperatur udara, kelembaban dan curah hujan) serta teknik budidaya (dengan dan tanpa mulsa). Penelitian bertujuan memperoleh varietas unggul kacang panjang polong ungu yang stabil dan beradaptasi umum dan atau spesifik lingkungan. Hipotesis yang diajukan yakni terdapat galur kacang panjang polong ungu yang stabil dan beradaptasi umum atau beradaptasi spesifik lingkungan.

\section{BAHAN DAN METODE}

Kegiatan penelitian terdiri atas penanaman kacang panjang di 6 unit lingkungan. Pelaksanaan penelitian di lingkungan 1 berlangsung di Desa Sumberporong, Lawang (Maret-Juli 2013; $435 \mathrm{~m} \mathrm{dpl;}$ akhir musim hujan; $22.60-24.50^{\circ} \mathrm{C}$; mulsa plastik hitam perak) dan lingkungan 2 dilaksanakan di Desa Srigading, Lawang (Maret-Juli 2013; 620 m dpl; akhir musim hujan; $22.60-24.50^{\circ} \mathrm{C}$; mulsa plastik hitam perak). Penelitian di lingkungan 3 (Maret-Juli 2013; 330 mdpl; akhir musim hujan; $24.60-26.20^{\circ} \mathrm{C}$; mulsa plastik hitam perak), lingkungan 4 (Mei-September 2013; $330 \mathrm{~m} \mathrm{dpl}$; musim kemarau; $24.40-25.90^{\circ} \mathrm{C}$; mulsa plastik hitam perak), lingkungan 5 (September 2013-Januari 2014; 330 m dpl; akhir musim kemarau; $25.00-26.90{ }^{\circ} \mathrm{C}$; tanpa mulsa) dan lingkungan 6 (Februari-Juni 2015; 330 m dpl; musim hujan; 25.60 $-25.80^{\circ} \mathrm{C}$; tanpa mulsa) dilaksanakan di Desa Jatikerto Malang. Data penelitian di lingkungan 1 dan 2 diperoleh dari Cahyaningrum (2014) dan di lingkungan 3 dan 4 diperoleh dari Marmadion (2013). Bahan yang digunakan dalam penelitian ini terdiri atas enam galur harapan (BU 1, BU 2, BU 3, BU 4, BU 5, dan BU 6) serta 2 varietas pembanding (Bagong 2 dan Brawijaya 4).

Penelitian di tiap lingkungan menggunakan Rancangan Acak Kelompok (RAK) dengan tiga kali ulangan dan terdapat 24 petak percobaan berukuran $1 \times 5 \mathrm{~m}$. Tiap petak terdiri atas 2 baris, masing-masing terdapat 10 tanaman dengan jarak tanam $60 \times 50 \mathrm{~cm}$. Pengamatan dilakukan pada karakter umur awal berbunga, umur awal panen, jumlah polong, panjang polong, jumlah biji per polong, bobot per polong dan bobot polong per hektar. Data pengamatan setiap 
karakter pada masing-masing lingkungan dianalisis sesuai dengan prosedur analisis ragam RAK. Selanjutnya, dilakukan uji homogenitas ragam galat terhadap hasil analisis ragam setiap karakter dari 6 lingkungan dengan mengacu pada Metode Bartlett. Jika ragam galat seluruh lingkungan homogen dilanjutkan analisis ragam gabungan. Sumber ragam genotip x lingkungan memiliki nilai kuadrat tengah berbeda nyata dengan $\mathrm{F}$ tabel taraf 5\% dan 1\% dan dilanjutkan dengan uji perbedaan rata-rata menggunakan Uji Beda Nyata Jujur (BNJ) pada taraf $5 \%$.

Analisis stabilitas mengacu pada model regresi linear Eberhart dan Russel (1996) dimana parameter stabilitas ialah nilai koefisien regresi (b) dan simpangan regresi $\left(S_{d}^{2}\right)$ dengan model linear: $Y_{i j}=m+b_{i} \cdot I_{j}+\ddot{a}_{i j}$. Jika nilai koefisien regeresi tidak berbeda nyata dengan satu ( $b=1)$ dan $\mathrm{S}_{\mathrm{d}}^{2}$ mendekati nol $\left(\mathrm{S}_{\mathrm{d}}{ }^{2}=0\right)$ maka genotip menunjukkan penampilan yang stabil. Penilaian adaptabilitas dari suatu genotip dilakukan dengan metode Finlay dan Wilkinson (1963) yakni didasarkan pada nilai koefisien regresi (b). Nilai $b=1$ menunjukkan bahwa genotip memiliki tingkat adaptasi umum. Nilai b $>1$ menunjukkan tingkat adaptasi khusus terhadap lingkungan yang produktif/subur, sedangkan $b<1$ menunjukkan tingkat adaptasi khusus terhadap lingkungan yang tidak produktif/tidak subur. Pengujian b dilakukan menggunakan uji t 5\% dan pengujian $\mathrm{S}_{\mathrm{d}}{ }^{2}$ menggunakan uji F 5\%. Perhitungan Indeks lingkungan $\left(\mathrm{I}_{\mathrm{j}}\right)$ dapat dihitung dari selisih antara rerata seluruh genotip pada suatu lingkungan dengan rerata total semua lingkungan (Nath and Dasgupta, 2013).

\section{HASIL DAN PEMBAHASAN}

Penampilan kacang panjang dipengaruhi oleh faktor genotip dan faktor lingkungan. Berdasarkan hasil analisis ragam, semua galur kacang panjang menunjukkan perbedaan nyata pada tujuh parameter yang diamati (Tabel 1). Hal ini menunjukkan ekspresi gen tiap galur dipengaruhi oleh faktor genotip. Gengen diantara galur beragam dan berperan aktif dalam memunculkan sifat fenotip yang berbeda (Karimizadeh

Tabel 1. Kuadrat Tengah Genotip Tujuh Karakter Komponen Hasil dan Hasil Kacang Panjang di Enam Lingkungan

\begin{tabular}{lrrrrrr}
\hline \multicolumn{1}{c}{ Karakter } & Lingkungan 1 & Lingkungan 2 & Lingkungan 3 & Lingkungan 4 & Lingkungan 5 & Lingkungan 6 \\
\hline UB & $48.93^{* *}$ & $55.71^{* *}$ & 1.81 & $17.42^{* *}$ & $4.76^{* *}$ & $5.09^{* *}$ \\
UP & $43.76^{* *}$ & $24.57^{* *}$ & 2.28 & 2.48 & $10.95^{* *}$ & $4.74^{* *}$ \\
JP & $310.11^{* *}$ & $285.54^{* *}$ & $332.88^{* *}$ & $163.98^{* *}$ & $97.81^{* *}$ & $151.83^{* *}$ \\
PP & $352.00^{* *}$ & $335.18^{* *}$ & $264.11^{* *}$ & $276.07^{* *}$ & $91.91^{* *}$ & $287.90^{* *}$ \\
JB & $5.83^{* *}$ & $7.24^{* *}$ & $8.81^{* *}$ & $15.66^{* *}$ & 2.03 & $5.52^{* *}$ \\
BP & $48.82^{* *}$ & $40.00^{* *}$ & $39.80^{* *}$ & $30.76^{* *}$ & $15.69^{* *}$ & $41.81^{* *}$ \\
BPH & $26.23^{* *}$ & $20.32^{* *}$ & $26.02^{* *}$ & $11.66^{* *}$ & $26.18^{* *}$ & $3.01^{*}$ \\
\hline
\end{tabular}

Keterangan: UB=Umur Awal Berbunga; UP=Umur Awal Panen; JP=Jumlah Polong; PP=Panjang Polong; JB=Jumlah Biji; $\mathrm{BP}=$ Berat per Polong; $\mathrm{BPH}=$ Berat Polong per Hektar; *berbeda nyata pada taraf uji F 5\%; **berbeda nyata pada taraf uji F $1 \%$ 
et al., 2013). Keragaman genotip memperbesar scope pemulia tanaman dalam memilih galur-galur unggul.

Pengamatan tujuh karakter menunjukkan ragam galat pada masing-masing lingkungan bersifat homogen (Tabel 2). Selanjutnya analisis ragam gabungan dilakukan untuk mengetahui pengaruh lingkungan dan interaksi genotip x lingkungan terhadap karakter yang diamati. Berdasarkan hasil analisis ragam gabungan, faktor lingkungan dan interaksi genotip dengan lingkungan berpengaruh signifikan terhadap karakter umur berbunga, umur panen, jumlah polong, panjang polong, jumlah biji, bobot per polong dan bobot polong per hektar (Tabel 3). Hasil analisis tersebut membuktikan bahwa faktor lingkungan dan interaksi genotip dengan lingkungan berpengaruh nyata terhadap perbedaan penampilan galur (Tadesse dan Fetien, 2011; Paran dan Zamir, 2003).

Telah diketahui bahwa perbedaan penampilan tidak hanya dipengaruhi oleh faktor genotip, tetapi juga dipengaruhi oleh faktor lingkungan. Genotip tertentu menunjukkan penampilan sesuai dengan harapan pada lingkungan tertentu, tetapi dapat mengalami perubahan jika ditanam pada lingkungan yang lain (Kuswanto et al., 2006). Perubahan tersebut dapat berupa peningkatan drastis atau sebaliknya berupa penurunan nilai suatu penampilan. Oleh karena itu, analisis terhadap interaksi genotip dengan lingkungan penting dilakukan untuk mengidentifikasi genotip beradaptasi spesifik atau beradaptasi luas (Sabaghnia et al., 2012).

Pendekatan regresi linear digunakan dalam menentukan stabilitas dan adaptabilitas genotip yakni berdasarkan koefisien regresi (Finlay dan Wilkinson, 1963). Eberhart dan Russell merumuskan dan menyatakan kestabilan genotip tidak cukup dengan nilai koefisien regresi (b), akan tetapi harus mempertimbangkan nilai simpangan regresi $\left(\mathrm{S}_{\mathrm{d}}^{2}\right)$. Koefisien regresi lebih dari 1 bermakna bahwa setiap peningkatan satu satuan indeks lingkungan berimbas pada peningkatan lebih dari satu satuan nilai karakter yang diamati. Genotip dengan koefisien regresi sama

Tabel 2. Analisis Homogenitas Ragam Galat Tujuh Karakter Komponen Hasil dan Hasil Kacang Panjang di Enam Lingkungan

\begin{tabular}{|c|c|c|c|c|c|c|c|c|}
\hline \multirow{2}{*}{ Lingkungan } & \multirow{2}{*}{$\mathrm{db}$} & \multicolumn{7}{|c|}{ Ragam Galat Karakter } \\
\hline & & UB & UP & $\mathrm{JP}$ & $\mathrm{PP}$ & JB & $\mathrm{BP}$ & $\mathrm{BPH}$ \\
\hline Lingkungan 1 & 14 & 0.13 & 0.18 & 23.00 & 11.70 & 0.56 & 0.19 & 0.91 \\
\hline Lingkungan 2 & 14 & 0.13 & 0.12 & 37.89 & 11.65 & 1.20 & 0.13 & 1.12 \\
\hline Lingkungan 3 & 14 & 0.41 & 0.28 & 35.84 & 17.33 & 1.09 & 0.23 & 1.39 \\
\hline Lingkungan 4 & 14 & 0.46 & 0.28 & 17.82 & 16.90 & 1.12 & 0.51 & 0.61 \\
\hline Lingkungan 5 & 14 & 0.18 & 0.47 & 39.27 & 5.03 & 1.21 & 0.22 & 2.40 \\
\hline Lingkungan 6 & 14 & 0.27 & 0.31 & 11.38 & 10.48 & 0.83 & 0.17 & 0.86 \\
\hline $\mathcal{X}_{\text {hitung }}$ & & 10.86 & 7.10 & 7.64 & 6.00 & 2.80 & 5.73 & 8.00 \\
\hline$\overline{\chi_{\text {tabel }}}$ & & 11.07 & 11.07 & 11.07 & 11.07 & 11.07 & 11.07 & 11.07 \\
\hline
\end{tabular}

Keterangan: UB=Umur Awal Berbunga; UP=Umur Awal Panen; JP=Jumlah Polong; PP=Panjang Polong; JB=Jumlah Biji; $\mathrm{BP}=$ Berat per Polong; $\mathrm{BPH}=$ Berat Polong per Hektar;* berbeda nyata pada taraf uji $\chi^{2} 5 \%$, db=derajat bebas 
Tabel 3. Kuadrat Tengah Genotip Analisis Ragam Gabungan Karakter Komponen Hasil dan Hasil Kacang Panjang di Enam Lingkungan

\begin{tabular}{|c|c|c|c|c|c|c|c|c|}
\hline \multirow{2}{*}{$\begin{array}{c}\text { Sumber } \\
\text { Keragaman }\end{array}$} & \multirow{2}{*}{$\mathrm{db}$} & \multicolumn{7}{|c|}{ Kuadrat Tegah Karakter } \\
\hline & & UB & UP & JP & PP & JB & $\mathrm{BP}$ & $\mathrm{BPH}$ \\
\hline Lingkungan & 5 & $65.64 * *$ & $98.19 * *$ & $1542.00^{* *}$ & $438.43 * *$ & $77.85^{* *}$ & $22.20^{* *}$ & $67.93^{* *}$ \\
\hline Ulg./Lingkungan & 12 & $0.50 * *$ & $0.58 * *$ & 46.73 & $25.16^{* *}$ & $2.92 * *$ & $1.32 * *$ & 2.28 \\
\hline Genotip & 7 & $49.16^{*}$ & $28.45^{*}$ & $590.56^{* *}$ & $1450.65^{* *}$ & $152.46^{* *}$ & $192.24 * *$ & $72.44 * *$ \\
\hline Gen. x Lingk. & 35 & $16.91^{* *}$ & $12.06^{* *}$ & $150.32 * *$ & $31.30^{* *}$ & $4.66^{* *}$ & $4.93 * *$ & $8.19^{* *}$ \\
\hline Galat Gabungan & 84 & 0.26 & 0.27 & 27.53 & 12.18 & 1.00 & 0.24 & 1.22 \\
\hline Total & 143 & & & & & & & \\
\hline
\end{tabular}

dengan satu memberikan respon standar pada semua kondisi lingkungan. Genotip dengan nilai koefisien regresi kurang dari satu bersifat adaptifpada lingkungan marjinal (tidak produktif). Respon genotip pada lingkungan marjinal menunjukkan penampilan terbaik. Sebaliknya, respon genotip buruk pada lingkungan produktif. Dengan demikian, genotip tersebut dapat direkomendasi untuk ditanam pada lahan marginal.

Nilai simpangan regresi memiliki kontribusi dalam mengetahui sebaran nilai dari rerata nilai karakter teramati dalam analisis stabilitas. Simpangan regresi mendekati nol menunjukkan bahwa nilai karakter suatu genotip cenderung mendekati rerata nilai dari genotip tersebut di semua lingkungan. Genotip dengan nilai simpangan regresi lebih besar dari nol menunjukkan sebaran data yang bervariasi dan dapat diartikan sensitif terhadap perubahan lingkungan (Karadavut et al., 2010). Sehingga, besar kemungkinan terdapat genotip pada lingkungan tertentu memiliki nilai menyimpangjauh dari rerata nilai karakter teramati dan tergolong tidak stabil.

Dalam penelitian ini, terdapat 2 kriteria lingkungan yakni lingkungan produktif dengan nilai indeks lingkungan positif dan lingkungan tidak produktif dengan nilai indeks lingkungan negatif(Bisawas et al., 2014). Nilai indeks lingkungan berbeda di antara karakter yang diamati. Lingkungan produktif dinilai berdasarkan nilai rata-rata penampilan dan indeks lingkungan yang tinggi (Waluyo dan Kuswanto, 2010). Beberapa lingkungan menunjukkan indek lingkungan bernilai negatif pada satu karakter dan bernilai positif pada karakter yang lain. Kriteria kondisi penanaman lingkungan 1 dan 2 merupakan dataran tengah (435 dan $620 \mathrm{~m} \mathrm{dpl)} \mathrm{dengan} \mathrm{suhu} \mathrm{rata-rata} 22.60-24.50$ ${ }^{\circ} \mathrm{C}$. Lingkungan 3 dan 6 bertempat di dataran rendah dan penanaman berlangsung saat musim hujan. Curah hujan tercatat antara 192,5 - 484,7 mm/hari. Sementara lingkungan 4 dan 5 bertempat di dataran rendah dan penanaman berlangsung pada musim kemarau. Lingkungan 1 hingga lingkungan 4 menerapkan aplikasi mulsa, sedangkan lingkungan 5 dan 6 tanpa aplikasi mulsa. Penggunaan mulsa maupun tanpa mulsa tidak banyak berbengaruh terhadap hasil panen kacang panjang. Namun, penggunaan mulsa lebih 
dianjurkan karena dapat mengurangi pertumbuhan gulma sehingga persaingan unsur hara dapat dikendalikan serta menjadikan kondisi tanah lebih sesuai bagi pertumbuhan kacang panjang (Susila, 2009).

Terkait karakter umur berbunga, Gambar 1 (kiri) menunjukkan kemiringan garis BU 2 berbeda dengan galur uji dan varietas. Hal tersebut diartikan bahwa umur berbunga BU 2 semakin lambat seiring dengan penurunan nilai indeks lingkungan. Sebaliknya, BU 2 berbunga lebih awal pada lingkungan dengan indeks positif(lingkungan 3, 4, dan 5) dengan curah hujan rendah hingga sedang. Lingkungan 1 dan 2 memiliki curah hujan yang rendah namun lingkungan tersebut terletak pada dataran tengah dengan temperatur udara rendah. Temperatur yang rendah dapat menghambat pembentukan bunga (Wallace et al., 1991).

Semua galur uji memiliki umur awal panen lebih lambat dibandingkan Bagong 2 dan Brawijaya 4. Posisi garis linear Bagong 2 dan Brawijaya 4 berada di bawah garis linear semua galur uji (Gambar 1, kanan). Garis linear Bagong 2 menggambarkan umur panen lebih awal seiring peningkatan nilai indeks lingkungan. Dalam penetian ini, lingkungan 1 dan 2 memiliki nilai indeks positif dengan karakteristik lingkungan kelembaban udara yang tinggi dan temperatur udara rendah. Thomas dan Raper (1983) mengemukakan bahwa pada temperatur udara rendah, proses pembentukan polong berlangsung lebih lambat. Waktu panen paling efektif pada kacang panjang untuk konsumsi segar yakni antara $10-15$ hari setelah bunga mekar karena akumulasi nutrisi pada polong telah maksimal (Ofori dan Klogo, 2005).

Karakter umur berbunga dan umur panen berkaitan erat dengan karakter jumlah polong per tanaman. Galur dengan umur berbunga dan umur panen lebih awal akan menghasilkan polong dalam jumlah lebih banyak (Sa'diyah et al., 2015). Akan tetapi, Bagong 2 dan Brawijaya 4 dengan umur berbunga dan umur panen lebih awal menghasilkan jumlah polong sedikit. Grafik hubungan koefisien regresi dengan jumlah polong menunjukkan bahwa galur BU 1 dan BU 6 menghasilkan polong lebih banyak dibandingkan dengan varietas (Gambar 2). Kedua galur tersebut
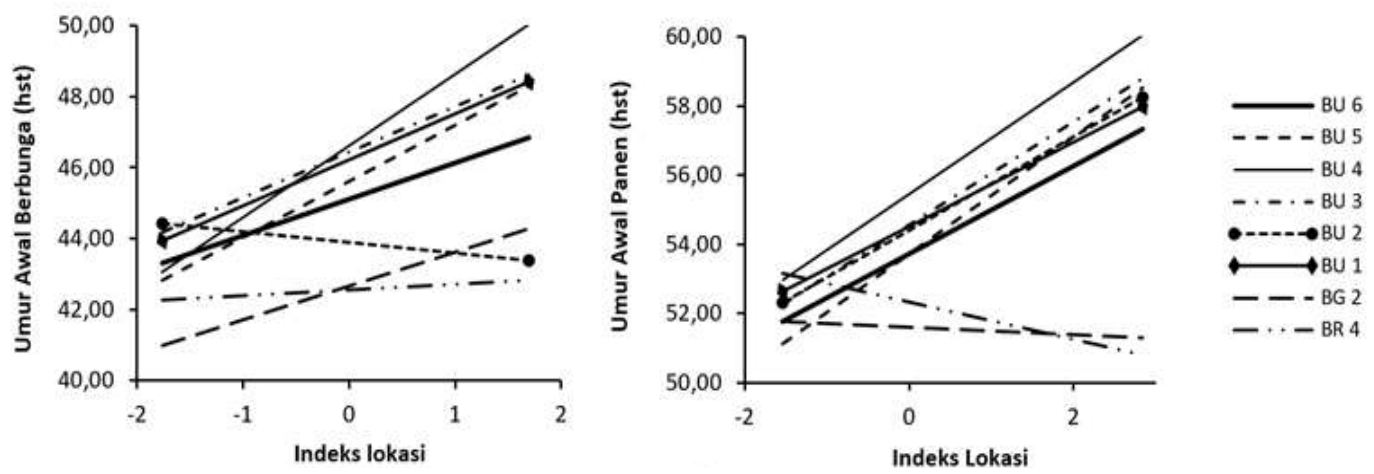

Gambar 1.Grafik hubungan umur awal berbunga dengan indeks lingkungan (kiri) dan umur awal panen dengan indeks lingkungan (kanan) 


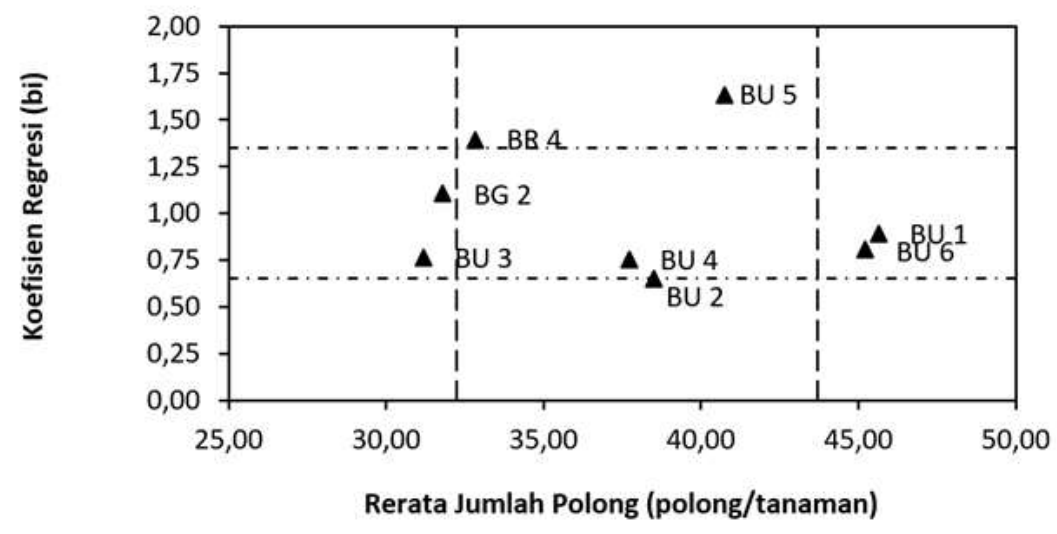

Gambar 2. Grafik hubungan koefisien regresi $\left(b_{i}\right)$ dengan rerata jumlah polong per tanaman
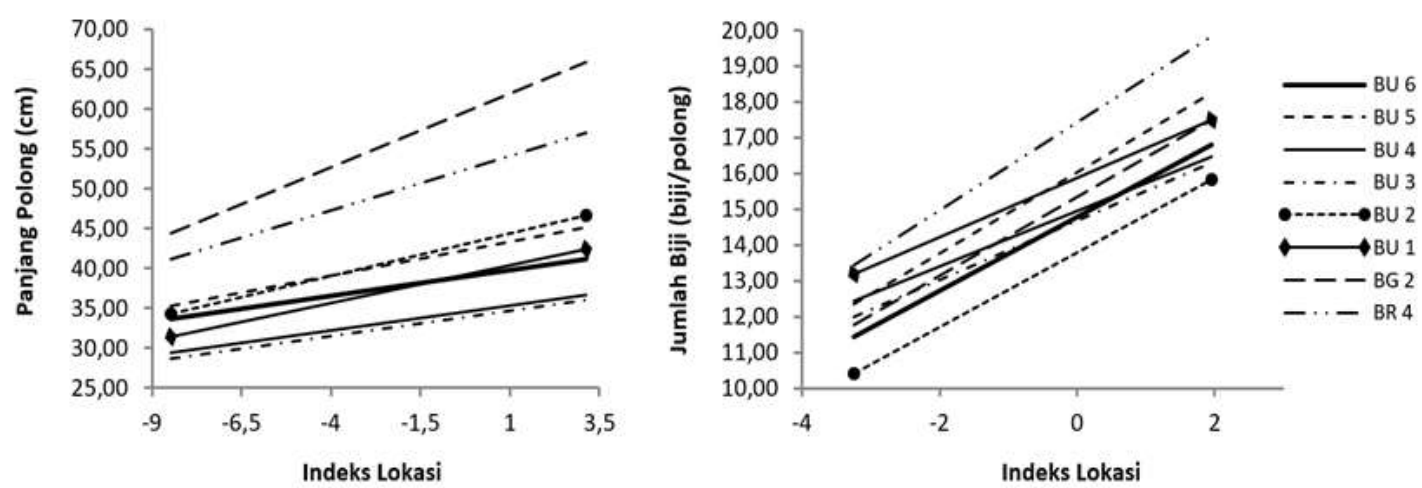

Gambar 3. Grafik hubungan panjang polong dengan indeks lingkungan (kiri) dan jumlah biji per polong dengan indeks lingkungan (kanan)

menghasilkan polong diatas standar rata-rata (garis vertikal kanan mewakili batas atas standar rata-rata jumlah polong) dengan koefisien regresi dalam standar rata-rata.

Polong yang dihasilkan oleh semua galur uji berukuran panjang pada lahan produktif(Gambar 3, kiri). Lahan produktif yakni lingkungan 1, 2, 3, 4 dan 6 , memiliki kondisi lingkungan yang mendukung pembentukan dan pematangan polong. Rerata ukuran polong galur BU $3(28.00-36.76 \mathrm{~cm})$ lebih pendek dibandingkan Bagong $2(44.66-67.01 \mathrm{~cm})$ dan Brawijaya 4 (40.98-58.26 cm). Galur BU 2 dan BU 5 memiliki keunggulan polong lebih panjang dibandingkan galur uji yang lain yakni dengan rentang panjang polong berturut-turut $35.08-49.54 \mathrm{~cm}$ dan $34.51-48.52 \mathrm{~cm}$. Perbedaan penampilan panjang polong dapat diakibatkan interaksi genotip lingkungan (Pan et al., 2006).

Polong panjang tidak selalu menghasilkan biji lebih banyak. Gambar 3 (kiri) menggambarkan posisi garis linier Bagong 2 berada di atas garis Brawijaya 4. Namun, pada Gambar 3 (kanan) garis linier Brawijaya 4 berada di atas garis Bagong 2. Hal tersebut menunjukkan bahwa Bagong 2 memiliki polong 
panjang menghasilkan jumlah biji lebih sedikit dibandingkan Brawijaya 4. Diantara galur uji, hanya BU 5 yang memiliki jumlah biji paling banyak. Perubahan jumlah biji semua galur berbanding lurus dengan perubahan nilai indeks lingkungan. Semakin tinggi nilai indeks lingkungan, maka jumlah biji cenderung meningkat. Lingkungan dengan indeks positif antara lain lingkungan 1, 2, 3, dan 6. Lingkungan 4 dan 5 memiliki indeks lingkungan negatif dengan intensitas curah hujan relatiftinggi. Pada kondisi tersebut serangan hama ulat penggerek polong cukup tinggi sehingga jumlah biji yang terbentuk sedikit. Karakter jumlah biji tidak selalu menjadi prioritas dalam pemilihan galur unggul karena panen segar bukan hanya berdasarkan jumlah biji, tetapi berdasarkan rasa, tekstur, dan penampilan polong kancang panjang secara umum (Kongjaimun et al., 2012). Meski demikian, jumlah biji mempengaruhi berat per polong dan hasil panen (Lovely dan Radhadevi, 2006).

Karakter panjang polong dan jumlah biji menunjang penampilan bobot per polong. Semua galur yang diuji memiliki rerata berat per polong lebih rendah dibandingkan dengan Bagong 2 dan Brawijaya 4 (Gambar 4). Penampilan bobot per polong galur BU 2 dapat diprediksi karena memiliki simpangan regresi tidak berbeda nyata dengan nol (ditunjukkan dengan simbol dot “"̈\%”" pada grafik). Diantara galur yang diuji, BU 5 memiliki rerata berat per polong paling tinggi. Pada dasarnya, polong panjang dengan jumlah biji banyak menghasilkan polong lebih berat dibandingkan polong pendek dengan jumlah biji sedikit. Dalam hal ini, galur BU 5 menunjukkan konsistensi hubungan ketiga karakter tersebut yakni memiliki polong panjang dan jumlah biji banyak sehingga polong yang terbentuk lebih berat dibandingkan galur uji yang lain.

Bobot polong per hektar berkaitan erat dengan jumlah polong dan bobot per polong. Jumlah polong per tanaman dan bobot per polong yang tinggi dapat menghasilkan bobot polong total per hektar yang tinggi pula (Ullah et al., 2011). Namun, galur BU 1 dan BU 6 memiliki polong dalam jumlah banyak dengan berat per polong rendah, akan tetapi menghasilkan bobot

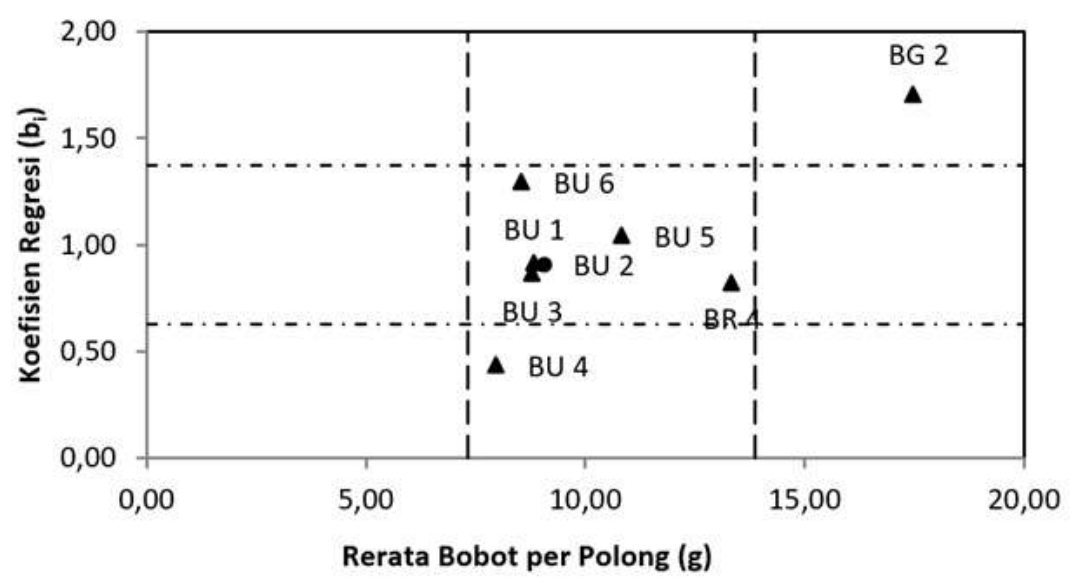

Gambar 4. Grafik hubungan koefisien regresi $\left(b_{i}\right)$ dengan rerata bobot per polong 
polong per hektar yang tinggi. Galur BU 5 menghasilkan bobot polong per hektar paling tinggi didukung dengan bobot per polong yang tinggi namun dengan jumlah polong lebih rendah dibandingkan galur BU 1 dan BU 6. Hal ini membuktikan bahwa, galur dengan jumlah polong banyak dan bobot per polong yang tinggi tidak selalu menghasilkan bobot polong per hektar yang tinggi.

Rata-rata bobot polong per hektar Bagong 2 menunjukkan nilai tertinggi (Tabel 4). Galur BU 5 berpotensi menghasilkan polong per hektar lebih tinggi dibandingkan Brawijaya 4. Akan tetapi, galur BU 5 memiliki koefisien regresi lebih besar dari 1. Galur BU 5 menunjukkan perubahan drastis seiring dengan peningkatan nilai indeks lingkungan. Dalam penelitian ini, bobot polong per hektar yang dihasilkan galur BU 5 pada lingkungan 1, 2, 3, 4, dan 6 berbeda jauh dengan hasil pada lingkungan 5. Lingkungan 5 dengan indeks lingkungan 3.06 memiliki kriteria dataran rendah ditanam saat awal musim kemarau. Sebaliknya, galur BU 2 dan BU 3 menunjukkan adaptabilitas pada lahan marjinal. Hasil bobot polong per hektar galur BU 2 dan BU 3 antara lingkungan 1, 2, 3 dan 6 (lahan marjinal dengan indeks lingkungan negatif) dengan lingkungan 4 dan 5 (lahan produktif dengan indeks lingkungan positif) tidak jauh berbeda dibandingkan dengan respon yang ditunjukkan oleh galur BU 5.

Ditinjau dari nilai koefisien regresi dan simpangan regresi, tidak terdapat galur yang stabil. Beberapa galur yang di uji memiliki nilai koefisien regresi tidak berbeda dengan satu dan menunjukkan adaptasi umum. Galur yang dimaksud antara lain galur BU 1 , BU 4, dan BU 6. Ketiga galur tersebut berada diantara batas atas dan bawah standar rata-rata koefisien regresi yang ditunjukkan dengan garis-garis horizontal (Gambar 5). Galur BU 4 terletak di bawah batas standar ratarata bobot polong per hektar (garis vertikal kiri). Galur BU 1 dan BU 6 berada dalam standar rata-rata bobot polong per hektar. Hal tersebut menandakan indikasi potensi galur BU 1 dan BU 6 dalam menghasilkan rerata bobot polong per hektar mendekati rata-rata Brawijaya 4. Galur unggul tidak harus memiliki karakter hasil

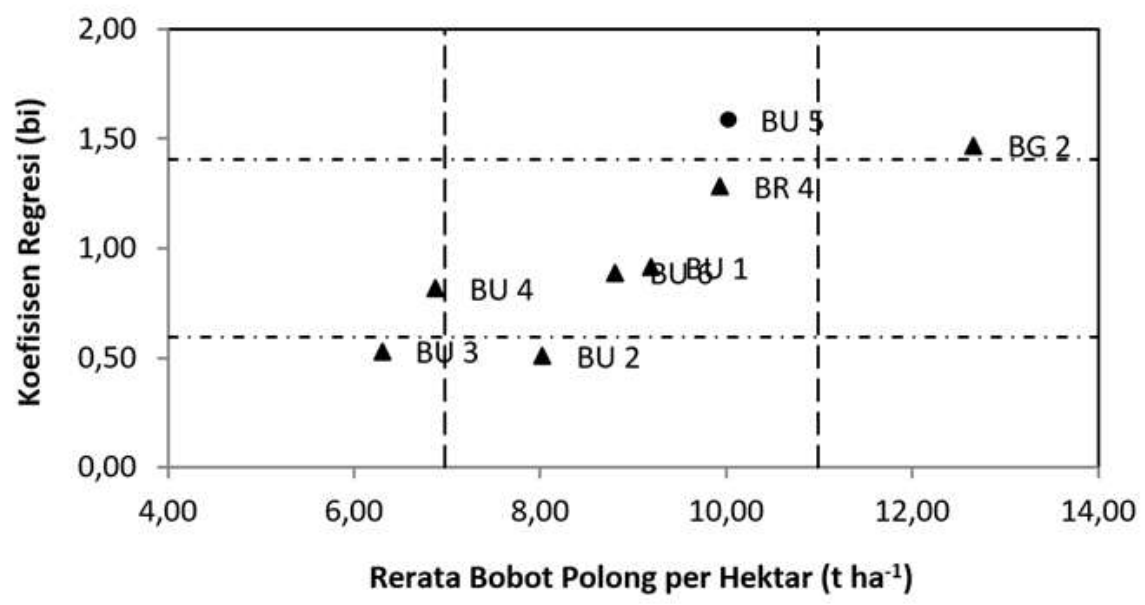

Gambar 5. Grafik hubungan koefisien regresi $\left(b_{i}\right)$ dengan bobot polong per hektar 
Tabel 4. Bobot polong per hektar $\left(\mathrm{t} \mathrm{ha}^{-1}\right) 6$ galur kacang panjang polong ungu dan 2 galur pembanding di 6 lingkungan

\begin{tabular}{lccccccccc}
\hline \multicolumn{1}{c}{ Galur } & Lingkungan 1 & Lingkungan 2 & Lingkungan 3 & Lingkungan 4 & Lingkungan 5 & Lingkungan 6 & Rerata & $\mathrm{b}_{\mathrm{i}}$ & $\mathrm{S}_{\mathrm{d}}{ }^{2}$ \\
\hline BU 1 & $9.07 \mathrm{~b}$ & $9.17 \mathrm{bc}$ & $11.20 \mathrm{ab}$ & $8.73 \mathrm{bc}$ & $11.32 \mathrm{~cd}$ & $5.66 \mathrm{a}$ & 9.19 & 0.91 & $1,93^{*}$ \\
BU 2 & $7.32 \mathrm{~b}$ & $7.61 \mathrm{~cd}$ & $8.72 \mathrm{bc}$ & $6.48 \mathrm{c}$ & $10.13 \mathrm{cde}$ & $7.92 \mathrm{a}$ & 8.03 & $0.51^{*}$ & $0,62^{*}$ \\
BU 3 & $4.46 \mathrm{c}$ & $5.30 \mathrm{~d}$ & $4.73 \mathrm{~d}$ & $7.90 \mathrm{bc}$ & $8.30 \mathrm{e}$ & $7.07 \mathrm{a}$ & 6.30 & $0.53^{*}$ & $2,06^{*}$ \\
BU 4 & $4.43 \mathrm{c}$ & $6.16 \mathrm{~d}$ & $5.45 \mathrm{~d}$ & $8.12 \mathrm{bc}$ & $9.82 \mathrm{de}$ & $7.31 \mathrm{a}$ & 6.88 & 0.82 & $1,91^{*}$ \\
BU 5 & $7.93 \mathrm{~b}$ & $9.56 \mathrm{bc}$ & $10.58 \mathrm{ab}$ & $9.71 \mathrm{~b}$ & $14.98 \mathrm{ab}$ & $7.41 \mathrm{a}$ & 10.03 & $1.58^{*}$ & $-0,21$ \\
BU 6 & $6.45 \mathrm{bc}$ & $7.85 \mathrm{~cd}$ & $10.10 \mathrm{bc}$ & $8.88 \mathrm{bc}$ & $11.50 \mathrm{~cd}$ & $8.03 \mathrm{a}$ & 8.81 & 0.89 & $0,75^{*}$ \\
Bagong 2 & $13.55 \mathrm{a}$ & $13.06 \mathrm{a}$ & $13.30 \mathrm{a}$ & $10.47 \mathrm{ab}$ & $17.36 \mathrm{a}$ & $8.24 \mathrm{a}$ & 12.66 & $1,47^{*}$ & $3,83^{*}$ \\
Brawijaya 4 & $9.21 \mathrm{~b}$ & $11.44 \mathrm{ab}$ & $7.32 \mathrm{~cd}$ & $13.05 \mathrm{a}$ & $12.91 \mathrm{~b} \mathrm{c}$ & $5.68 \mathrm{a}$ & 9.93 & 1,28 & $5,32^{*}$ \\
Indeks & -1.18 & -0.21 & -0.05 & 0.20 & 3.06 & -1.82 & & & \\
Lingkungan & & & & & & & & \\
\hline
\end{tabular}

Keterangan: Angka pada kolom yang sama dan diikuti huruf kecil sama tidak berbeda berdasarkan uji BNJ á 5\%; b = koefisien regresi, $\mathrm{Sd}_{\mathrm{i}}^{2}=$ simpangan regresi, $*$ = berbeda nyata dari 1 berdasarkan uji $\mathrm{t}$ taraf $5 \%$ atau berbeda nyata dari 0 berdasarkan uji F 5\%

panen stabil dan mampu beradaptasi umum. Perlu diketahui bahwa hasil uji stabilitas dan adaptabilitas berfungsi dalam memberikan informasi terkait respon galur terhadap kondisi lingkungan penanaman sehingga varietas yang dilepas dapat direkomendasikan pada spesifik lingkungan atau pada semua tipe lingkungan.

Bobot polong per hektar merupakan karakter penting dalam penentuan galur unggul. Namun, perlu diperhatikan bahwa penentuan galur terbaik bukan hanya berdasarkan pada bobot polong per hektar, tetapi juga berdasarkan karakter komponen hasil yang lain (Huque et al, 2012). Selain itu, Peraturan Menteri Pertanian tentang pendaftaran varietas tanaman hortikultura, No. 38 Tahun 2011 menjelaskan bahwa varietas unggul merupakan varietas yang mempunyai kelebihan dalam potensi hasil dan/atau sifat-sifat yang lainnya. Berdasarkan deskripsi galur, semua galur menunjukkan keunggulan warna polong ungu. Warna polong ungu erat hubungannya dengan kadar antosianin. Diantara galur harapan kacang panjang polong ungu, galur BU 3 menunjukkan kadar antosianin tertinggi sebesar 189,54 ppm (Paramitha, et al., 2018).

\section{KESIMPULAN}

Hasil penelitian ini menunjukkan galur BU 1 memiliki keunggulan bobot polong per hektar dengan rerata hasil yang tinggi $\left(9,19 \mathrm{t} \mathrm{ha}^{-1}\right)$ diikuti oleh galur BU $6\left(8,81 \mathrm{t} \mathrm{ha}^{-1}\right)$ dan BU $4\left(6,88 \mathrm{t} \mathrm{ha}^{-1}\right)$ dengan kemampuan beradaptasi umum untuk semua tipe lingkungan. Galur BU $2\left(8,03 \mathrm{t} \mathrm{ha}^{-1}\right)$ menunjukkan keunggulan dalam menghasilkan bobot polong per hektar optimal pada lahan marjinal, sedangkan galur BU 5 (10,03 tha $\left.\mathrm{t}^{-1}\right)$ beradaptasi pada lahan produktif. Berdasarkan deskripsi galur, seluruh galur memiliki keunggulan warna polong ungu dan secara khusus galur BU 3 memiliki keunggulan kadar antosianin paling tinggi diantara galur yang diuji.

\section{UCAPAN TERIMA KASIH}

Penulis menyampaikan ucapan terima kasih 
kepada Prof. Dr. Ir. Kuswanto, MS., Dr. Ir. Damanhuri, MS., serta semua pihak yang telah membantu penyusunan dan penyelesaian penelitian.

\section{DAFTAR PUSTAKA}

Asfaw, A., T. Assefa, B. Amsalu, K. Negash, F. Alemayehu, F. Gurum, Y. Rezene, C. Finenissa, M. Atnafi, dan C. Daba. 2008. Adaptation and yield of small red bean elite lines in Ethiopia. International J. of Plant Breeding and Genetics 2(2): $51-63$.

Baihaki, A. 1990. Peningkatan produktivitas kedelai melalui rekayasa tanaman. Seminar Nasional Sehari. STO Tanjungpura. Sumedang.

Bisawas, A., U. Sarker, B.R. Banik, M.M. Rohman, M.Z.A. Talukder. 2014. Genotype x environment interacrion for grain yield of maize (Zea mays L.) inbreds under salinity stress. Bangladesh J. Agric.Res. 39(2): 293 - 301.

Brown J. dan P.D.S. Caligary. 2008. An introduction to plant breeding. UK: Blackwell Publishing.

Choukan, R. 2011. Genotype, environment and genotype $\times$ environment interaction effects on th performance of maize (Zea mays L.) inbred lines. Crop Breeding Journal 1(2): 97 - 103.

Eberhart, S.A. dan W.A. Russel. 1966. Stability parameter for comparing varieties. Crop.Sci. 6: $36-40$.

Escobar, M., M. Berti, I. Matus, M. Tapia, dan B. Johnson. 2011. Genotip x environment interaction in canola (Brassica napus L.) seed yield in Chile. Chilean Journal of Agricultural Research. 71(2): $175-186$.
Finlay, K.W. dan G.N. Wilkinson. 1963. The analysis of adaptation in a plant breeding programme. Australian J. Agr. Res. 14 : 742 - 754.

Huque, A.M., M.K. Hossain, N. Alam, M. Hasanuzzaman dan B.K. Biswas. 2012. Genetic divergence in yardlong bean (Vigna unguiculata (L.) Walp. ssp. sesquipedalis Verdc.). Bangladesh J. Bot. 41(1): 61 - 69.

Karadavut, U., C. Palta, Z. Kavurmaci, Y Bolek. 2010. Some grain yield parameters of multi enveronmental trials in faba bean (Vicia faba) genotypes. J. Agric. Biol. 12: 217 - 220.

Karimizadeh, R., M. Mohammadi, N. Sabaghani,A.A. Mahmood, B. Roustami, F. Seyyedi, F. Akbari. 2013. GGE biplot analysis of yield stability in multi environment trials of lentil genotypes under rainfed condition. Not. Sci. Biol. 5(2): $256-262$.

Kasim, H. dan Djunainah. 1993. Deskripsi Varietas Unggul Palawija, Jagung, Sorghum, Kacang-kacangan dan Umbi-umbian, 1918-1982. Bogor: Pusat Penelitian dan Pengembangan Tanaman Pangan, Badan Penelitian dan Pengembangan Pertanian, Departemen Pertanian.

Kongjaimun, A., A. Kaga, N. Tomooka, P. Somta, D.A. Vaughan, dan P. Srinives. 2012. The genetics of domestication of yardlong bean Vigna unguiculata (L.) Walp. ssp. unguiculata cv.-gr. sesquipedalis. Ann.Bot.: $1-6$.

Kuswanto, N. Basuki, E.S. Rejeki. 2006. Uji adaptasi kacang panjang (Vigna sesquipedalis L. Fruwirth) Galur Unibraw. Habitat 17 (12): 103 $-117$. 
Kuswanto, B. Waluyo, and P. Hardinaningsih. 2013. Segregation and selection of observed yardlong bean (Vigna sesquipedalis L. Fruwirth) to get expected lines of purple pod. International Research Journal of Agricultural Science and Soil Science 3 (3): 88 - 92.

Laga, C., E. Cassani, C. Zanzi, M. Landoni, R. Trovato, dan R. Pilu. 2014. Development and study of a maize cultivar rich in anthocyanins: coloured polenta, a new functional food. Plant Breeding 133(2): 210 - 217.

Lovely, B. dan D.S. Radhadevi. 2006.Character Association Studies in Yardlong Bean (Vigna unguiculata ssp. sesquipedalis L. Verde.). Indian J. Plant Gen. Res. 19: 80 - 82.

Nath, D. dan T. Dasgupta. 2013. Genotype $x$ Environment Interaction and Stability Analysis ini Mugbean. IOSR J. of Agriculture and Veterinary Science 5 (1) : 62-70.

Ofori, K. dan P.Y. Klogo. 2005. Optimum time for harvesting yardlong bean (Vigna sesquipedalis) for high yield and quality of pods and seeds. J.Agr.Soc.Sci. 1 (2): $86-88$.

Pan, R.S., A.K. Singh, M. Rai, dan S. Kumar. 2006. Stability analysis of yield and its components in bush type french bean. Veg. Sci. 33(2): 145 -148 .

Paramitha, A. I. 2014. Uji daya hasil dan evaluasi potensi galur harapan kacang panjang ungu (Vigna sesqupedalis L. Fruwirth). Tesis. Universitas Brawijaya. Malang.

Paramitha, A. I., Damanhuri, dan Kuswanto. 2018. Potensi Galur Harapan Kacang Panjang Polong Ungu. Agroradix 2 (1): 32-37.
Paran, I.dan D. Zamir. 2003. Quantitative traits in plants: beyond the QTL. Trends in Genetics 19(6): $303-306$.

Sabaghnia, N., R. Karimizadeh, M. Mohammadi. 2012. Genotype by environment interaction and stability analysis for grain yield of lentil genotypes. Agriculture 99(3): 305-312.

Sa'diyah, N., C. R. Siagian., dan M. Barmawi. 2015. Korelasi dan Analisis Lintas Karakter Agronomi Kedelai (Glycine max [L.] Merril) Keturunan Persilangan Wilis X MLG 2521. Jurnal Penelitian Pertanian Terapan 16 (1): 45-53.

Singh, R. K. dan B. D. Chaudhary. 1979. Biometrical Methods in Quantitative Genetic Analysis. Kalyani Publishers. New Delhi.

Suda, I., T. Oki, M. Masuda, M. Kobayashi, Y. Nishiba, dan S. Furuta. 2003. Physiological functionality of purple-fleshed sweet potatoes containing anthocyanins and their utilization in foods. JARQ. 37(3): 167-173.

Susila, A.D. 2009. Vegetables production with polyethylene mulched and drip irrigation system. Kumpulan Makalah Seminar Ilmiah Perhorti: 335 - 343.

Tadesse, H. dan A. Fetien. 2011. Additive main effects and multiplicative interactions analysis of yield performance of sesame genotypes across environments in Nothern Ethiopia. Journal of The Drylands 4(1): 259 - 266.

Thomas, J.F. Dan C.D. Raper. 1983. Photoperiod and temperature regulation of floral initiation and anthesis in soya bean. Ann. Bot. 51(4): 481 489. 
Ullah, M.Z., M.J. Hasan, A.H.M.A. Rahman, A.I. Saki. 2011. Genetic variability, character association and path analysis in yardlong bean. SAARC J. Agri. 9 (2): 9 - 16.

Wallace, D.H., P.A. Gniffke, P.N. Masaya, R.W.Zobel. 1991. Photoperiod, temperature, and genotype interaction effects on days and nodes required for flowering of bean. J. Amer. Soc. Hort. Sci. 116(3): $534-543$.
Waluyo, B. dan Kuswanto. 2010. Stability and adaptability of nine open pollinated varieties of UB maize. Agrivita 32 (3): 293 - 301.

Zhao, C.L., H.C. Guo, Z.Y. Dong, dan Q. Zhou. 2009. Pharmalogical and nutritional activities of potato anthocyanins. African J. of Pharmacy and Pharmacology 2(10): 463 - 468. 